$$
\text { CONF } 960796-6 \quad \text { ANH/CHM/CP-- } 90258
$$

To be submitted for publication in the Journal of Alloys and Compounds as a contributed paper in the proceedings of the 21st Rare Earth Research Conference (Abstract PS-34), 2921 words, 4 figures.

\title{
Uranyl fluoride luminescence in acidic aqueous solutions
}

James V. Beitz ${ }^{1}$ and Clatyon W. Williams

Chemistry Division, Argonne National Laboratory, Argonne, IL 60439 (USA)

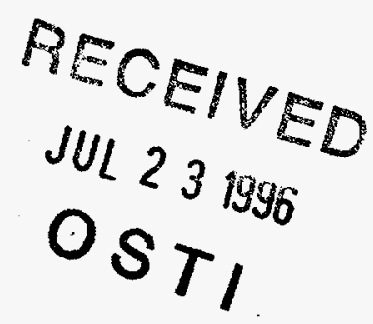

\section{Abstract}

Luminescence emission spectra and decay rates are reported for uranyl species in acidic aqueous solutions containing $\mathrm{HF}$ or added $\mathrm{NaF}$. The longest luminescence lifetime, $0.269 \pm 0.006 \mathrm{~ms}$, was observed from uranyl in $1 \mathrm{M} \mathrm{HF}+1 \mathrm{M} \mathrm{HClO}_{4}$ at $296 \mathrm{~K}$ and decreased with increasing temperature. Based on a luminescence dynamics model that assumes equilibrium among electronically excited uranyl fluoride species and free fluoride ion, this long lived uranyl luminescence in aqueous solution is attributed primarily to $\mathrm{UO}_{2} \mathrm{~F}_{2}$. Studies on the effect of added $\mathrm{LiNO}_{3}$ or $\mathrm{Na}_{2} \mathrm{WO}_{4} 2 \mathrm{H}_{2} \mathrm{O}$ showed relatively weak quenching of uranyl fluoride luminescence which suggests that high sensitivity determination of the $\mathrm{UF}_{6}$ content of $\mathrm{WF}_{6}$ gas should be feasible via uranyl luminescence analysis of hydrolyzed gas samples of impure $\mathrm{WF}_{6}$.

Keywords: uranyl, luminescence, speciation, uranium analysis, uranyl fluoride

\section{Introduction}

Determination of trace levels of uranium, present as $\mathrm{UF}_{6}$, in $\mathrm{WF}_{6}$ gas is challenging due to the chemically aggressive nature of transition metal hexafluorides. The presence of $\mathrm{UF}_{6}$ in $\mathrm{WF}_{6}$ is technologically important because $\mathrm{WF}_{6}$ is used to deposit tungsten metal in the

1Corresponding author. FAX: 708-252-4225, e-mail: beitz@anlchm.chm.anl.gov. $=$ 


\section{DISCLAIMER}

Portions of this document may be illegible in electronic image products. Images are produced from the best available original document. 
manufacture of integrated circuits (see, for example, [1]). Impurity $\mathrm{UF}_{6}$ in $\mathrm{WF}_{6}$ can result in deposition of uranium species which, due to radioactive decay, give rise to alpha particle-induced single event upsets that degrade integrated circuit reliability [2]. During the course of assessing the applicability of luminescence analysis for $U$ as uranyl in aqueous solutions resulting from hydrolysis of impure $\mathrm{WF}_{6}$ in diluted nitric acid, we observed uranyl luminescence decay times that increased with increasing amount of hydrolyzed gas. We were surprised because W(VI) in $1 \mathrm{M} \mathrm{H}_{3} \mathrm{PO}_{4}[3]$ is known to quench uranyl luminescence and decrease its luminescence lifetime. Prompted by this result, and because hydrolysis of $\mathrm{WF}_{6}$ generates both $\mathrm{W}(\mathrm{VI})$ and $\mathrm{HF}$, we investigated the influence of fluoride ion on uranyl luminescence lifetime in solutions of molar acidity.

Ours is not the first work on the influence of fluoride ion, $\mathrm{F}^{-}$, on uranyl luminescence. Enhancement of uranyl luminescence in aqueous solution via $\mathrm{F}^{-}$has long been exploited for analytical purposes. The study of Kaminski and coworkers[4] provides an example of such work and they cite earlier analytical studies. Moriyasu and coworkers[5] carried out a systematic study of the influence of fluoride on the luminescence lifetimes of $0.01 \mathrm{M}$ uranyl solutions. They reported that the uranyl luminescence decay rate at $298 \mathrm{~K}$ decreased with increasing fluoride concentration to a value, $6667 \mathrm{~s}^{-1}$, that remained constant from $0.06 \mathrm{M}$ to $1 \mathrm{M}$ fluoride and concluded that $\mathrm{UO}_{2} \mathrm{~F}_{2}, \mathrm{UO}_{2} \mathrm{~F}_{3}{ }^{-}$, and $\mathrm{UO}_{2} \mathrm{~F}_{4}{ }^{2-}$ have the same luminescence lifetimes. Billing and coworkers reported that the luminescence decay rate of $0.01 \mathrm{M}$ uranyl in $0.5 \mathrm{M} \mathrm{NaF}$ at $\mathrm{pH} 7.4$ is $6250 \pm 78 \mathrm{~s}^{-1}$ and ascribed the luminescence to the $\mathrm{UO}_{2} \mathrm{~F}_{4}{ }^{2-}[6]$. During the course of the present investigation, Moulin and coworkers reported that the luminescence decay rate of uranyl in $0.67 \mathrm{M} \mathrm{HF}$ is $3333 \mathrm{~s}^{-1}$ at $293 \mathrm{~K} \mathrm{[7]} \mathrm{and} \mathrm{assigned} \mathrm{the} \mathrm{luminescence} \mathrm{to} \mathrm{UO}_{2} \mathrm{~F}_{3}{ }^{-}$and $\mathrm{UO}_{2} \mathrm{~F}_{4}{ }^{2-}$. The nature of the luminescing state (or states) of uranyl and its complexes remains controversial. See 
Azenha and coworkers[8] for a recent review of several interpretations of uranyl luminescence as well as references to earlier studies and reviews.

\section{Experimental Details}

Reagent grade or more highly purified chemicals and Type 1 reagent grade water (per ASTM D1193) were used to prepare solutions. Stock solutions that contained HF were stored in high density polyethylene containers. Uranium was added as uranyl $\left(\mathrm{UO}_{2}{ }^{2+}\right)$ using a stock solution of uranyl in diluted nitric acid. Salts such as sodium tungstate dihydrate $\left(\mathrm{Na}_{2} \mathrm{WO}_{4} \cdot 2 \mathrm{H}_{2} \mathrm{O}\right)$ and $\mathrm{LiNO}_{3}$ were added in weighed amounts to an aliquot of a given acid stock solution. Based on weight changes, acidic $1 \mathrm{M} \mathrm{HF}$ solutions slowly attacked the fused silica cuvettes used for luminescence studies, although no visible etching was observed. Sample solutions were in contact with fused silica for at most a few hours, exhibited no discernible trend as to the influence of residence time on observed luminescence decay rate, and were discarded after undergoing analysis. The concentration stated for a particular chemical compound, such as $\mathrm{Na}_{2} \mathrm{WO}_{4} \cdot 2 \mathrm{H}_{2} \mathrm{O}$, in a given solution is the total (analytical) concentration of the stated material in the solution. Speciation calculations were carried out using a simplex minimization algorithm[9]. The stability constants of Ahrland and Kullberg[10] for fluoride-containing uranyl solutions of ionic strength 1 at $298 \mathrm{~K}$ were used, unless otherwise stated.

The excitation light source was a $337 \mathrm{~nm}$ nitrogen laser ( $2 \mathrm{~mJ} / \mathrm{pulse})$. Emission spectra were recorded using a time-gated, intensified, optical multichannel analyzer mounted on a spectrograph ( $0.5954 \mathrm{~nm}$ per datum) and have not been corrected for the spectral response of the detection system. Luminescence decays were recorded using optical filters that passed wavelengths longer than $470 \mathrm{~nm}$, a cooled GaAs photomultiplier, a variable value load resistor, and a signal averaging digital storage oscilloscope that was interfaced to a personal computer. 
The load resistance was varied to alter the response time of the detection system and thereby optimize signal-to-noise ratio. Nonlinear least squares fitting was carried out using either a single exponential decay model, $\mathrm{I}(t)=\operatorname{Aexp}\left(-k_{1} t\right)$, where $\mathrm{I}(t)$ is the observed luminescence intensity at time $t$ following the laser pulse and $\mathrm{A}$ and $k_{l}$ are parameters whose value was adjusted or a double exponential decay model, $\mathrm{I}(t)=\mathrm{A} \exp \left(-k_{1} t\right)+\mathrm{B} \exp \left(-k_{2} t\right)$, where $\mathrm{A}, k_{1}, \mathrm{~B}$, and $k_{2}$ are parameters whose value underwent nonlinear adjustment. The stated uncertainties in adjusted model parameters correspond to $95 \%$ confidence limits based on replicate determinations.

\section{Results}

The gated emission spectrum of uranyl in $1 \mathrm{M} \mathrm{HF}+1 \mathrm{M} \mathrm{HClO}_{4}$ is shown in Fig. 1. The observed spectra consist of vibronic bands $\left(846 \mathrm{~cm}^{-1}\right.$ average spacing) that are attributed to emission from uranyl fluoride complexes (primarily $\mathrm{UO}_{2} \mathrm{~F}_{2}$, as discussed below). The observed luminescence decay of uranyl ion in the same solution and corresponding best fit decay curve are shown in Fig. 2. The luminescence decay rate was temperature dependent: $k_{1}=3717 \pm 86 \mathrm{~s}^{-1}$ at $296 \mathrm{~K}$ and $4149 \pm 138 \mathrm{~s}^{-1}$ at $301 \mathrm{~K}$

Serial addition of weighed amounts of $\mathrm{NaF}$ to a solution initially containing $3 \times 10^{-6} \mathrm{M}$ uranyl in $0.1 \mathrm{M} \mathrm{HClO}_{4}$ was carried out and the luminescence decay of uranyl was recorded after each addition of NaF. The slowest decay rate $\left(\mathrm{k}_{1}=3846 \pm 89 \mathrm{~s}^{-1}\right.$ at $\left.299 \mathrm{~K}\right)$ was found for $1.3 \times 10^{-1} \mathrm{M}$ added $\mathrm{NaF}$ with faster decays observed at lower and higher concentrations of added $\mathrm{NaF}$ (see Fig. 3). To probe the influence of $\mathrm{NO}_{3}{ }^{-}$on the luminescence of uranyl fluorides, serial addition of $\mathrm{LiNO}_{3}$ to a solution of uranyl in $1 \mathrm{M} \mathrm{HF}+1 \mathrm{M} \mathrm{HClO}_{4}$ was carried out and luminescence decay data were recorded after each addition of $\mathrm{LiNO}_{3}$. Addition of $0.14 \mathrm{M}$, $0.27 \mathrm{M}$, and $0.58 \mathrm{M} \mathrm{LiNO}_{3}$ resulted in increasingly rapid luminescence decays whose curves were better fit by the double exponential decay model although with decay rate constants that 
differed by less than $35 \%$ for a given $\mathrm{LiNO}_{3}$ concentration. A final addition to give $0.98 \mathrm{M}$ $\mathrm{LiNO}_{3}$ resulted in a luminescence decay curve that was well fit by a single exponential decay model $\left(k_{1}=64700 \pm 940 \mathrm{~s}^{-1}\right)$. Analyzing the observed decays for $0.14 \mathrm{M}, 0.27 \mathrm{M}$, and $0.58 \mathrm{M}$ added $\mathrm{LiNO}_{3}$ as single exponential and carrying out a Stern-Volmer plot of that data gave a quenching rate parameter, $\mathrm{k}_{\mathrm{q}}$, of $(1.1 \pm 2) \times 10^{4} \mathrm{M}^{-1} \mathrm{~s}^{-1}$ for addition of $\mathrm{LiNO}_{3}$ to uranyl in $1 \mathrm{M} \mathrm{HF}$ $+1 \mathrm{M} \mathrm{HClO}_{4}$ at $301 \mathrm{~K}$. This value for quenching of uranyl fluoride luminescence by $\mathrm{NO}_{3}{ }^{-}$is somewhat smaller than the $(4.7 \pm 0.8) \times 10^{4} \mathrm{M}^{-1} \mathrm{~s}^{-1}$ value reported for quenching of $\mathrm{UO}_{2}{ }^{2+}$ by $\mathrm{NO}_{3}^{-}$ in nitric acid[11]. An emission spectrum (Fig. 1) recorded after the final $\mathrm{LiNO}_{3}$ addition was found to consist of a band identical to that of uranyl in $1 \mathrm{M} \mathrm{HF}+1 \mathrm{M} \mathrm{HClO}_{4}$ and a broad, relatively featureless, band that contained $24 \%$ of the total observed emission band area and is similar to that reported by Deniau and coworkers for uranyl in $1.6 \mathrm{M} \mathrm{HNO}_{3}$ [12].

The luminescence decay and emission spectrum of uranyl in $1 \mathrm{M} \mathrm{HF}+1 \mathrm{M} \mathrm{HNO}_{3}$ at $295 \mathrm{~K}$, following $337 \mathrm{~nm}$ excitation, were recorded before and after addition of $2.9 \times 10^{-2} \mathrm{M}$ $\mathrm{Na}_{2} \mathrm{WO}_{4} 2 \mathrm{H}_{2} \mathrm{O}$ to probe the influence of $\mathrm{W}(\mathrm{VI})$ on uranyl fluoride luminescence. The absence of new emission bands and faster decay upon addition of sodium tungstate argues that its primary effect is to collisionally quench uranyl luminescence. Based on the observed increase in uranyl luminescence decay rate, $\mathrm{k}_{\mathrm{q}}$ for dissolved tungstate (likely a present as a fluorotungstate complex[13]) is $1.7 \times 10^{5} \mathrm{M}^{-1} \mathrm{~s}^{-1}$ in $1 \mathrm{MHF}+1 \mathrm{M} \mathrm{HNO}_{3}$ at $295 \mathrm{~K}$ This differs little from the $\mathrm{k}_{\mathrm{q}}=$ $1.6 \times 10^{5} \mathrm{M}^{-1} \mathrm{~s}^{-1}$ value reported by Moriyasu and coworkers for W(VI) in $1 \mathrm{M} \mathrm{H}_{3} \mathrm{PO}_{4}$ at $298 \mathrm{~K}[3]$. 


\section{Discussion}

In Fig. 1, the observed luminescence bands agree, within experimental error, with the maxima reported by Billing and coworkers [6] as occurring from uranyl in $0.5 \mathrm{M} \mathrm{NaF}$ at $\mathrm{pH} 2$ and the uranyl in $0.67 \mathrm{M} \mathrm{HF}$ at $293 \mathrm{~K}$ spectrum reported by Moulin and coworkers[7]. The bands do differ from the reported emission spectrum of $\mathrm{UO}_{2} \mathrm{~F}^{+}$[14]. Using literature stability constants for $298 \mathrm{~K}$ and ionic strength 1 [10], we calculate that the predominant uranyl fluorides, as to mole fraction, $X$, in $1 \mathrm{M} \mathrm{HF}+1 \mathrm{M} \mathrm{HClO}_{4}$ are $\mathrm{UO}_{2} \mathrm{~F}^{+}(X=0.200), \mathrm{UO}_{2} \mathrm{~F}_{2}(X=0.607)$, and $\mathrm{UO}_{2} \mathrm{~F}_{3} \cdot(X=0.182)$. For $0.01 \mathrm{M}$ total uranyl in $0.5 \mathrm{M} \mathrm{NaF}$ at $\mathrm{pH} 2$, the majority uranyl species are $\mathrm{UO}_{2} \mathrm{~F}_{3}^{-}(X=0.447)$ and $\mathrm{UO}_{2} \mathrm{~F}_{4}{ }^{2-}(X=0.509)$. Using stability constants for ionic strength 0 at $298 \mathrm{~K}[15,16]$ for uranyl in $0.67 \mathrm{M} \mathrm{HF}$, the calculated dominant species are $\mathrm{UO}_{2} \mathrm{~F}_{2}(X=0.244)$ and $\mathrm{UO}_{2} \mathrm{~F}_{3}^{-}(X=0.683)$. Based on these speciation calculations, it not evident why uranyl in $1 \mathrm{M}$ $\mathrm{HF}+1 \mathrm{M} \mathrm{HClO}_{4}$, in $0.67 \mathrm{M} \mathrm{HF}$, and in $0.5 \mathrm{M} \mathrm{NaF}$ at $\mathrm{pH} 2$ gives rise to such similar emission spectra. Similar spectra would be expected if the equilibria among uranyl fluorides and free $\mathrm{F}^{-}$is sufficiently different for electronically excited uranyl complexes in comparison with those reported for ground state uranyl complexes[10] and such equilibria are established on a time scale shorter than the observed luminescence decay. As discussed below, this interpretation is supported by luminescence lifetime studies.

Moriyasu and coworkers studied the effect of fluoride concentration on uranyl luminescence decay at $298 \mathrm{~K}$ (see their Fig. 2) [5]. They reported that the luminescence decay rate of $\mathrm{UO}_{2} \mathrm{~F}^{+}$is $13333 \mathrm{~s}^{-1}$ and the decay rates of $\mathrm{UO}_{2} \mathrm{~F}_{2}, \mathrm{UO}_{2} \mathrm{~F}_{3}{ }^{-}$, and $\mathrm{UO}_{2} \mathrm{~F}_{4}{ }^{2-}$ are the same $\left(6667 \mathrm{~s}^{-1}\right)$ to within an unstated error limit. In contrast, we have observed a luminescence decay rate of $3717 \mathrm{~s}^{-1}$ from uranyl in $1 \mathrm{M} \mathrm{HF}+1 \mathrm{M} \mathrm{HClO}_{4}$ at $296 \mathrm{~K}$ and Moulin and coworkers reported $3333 \mathrm{~s}^{-1}$ for uranyl in $0.67 \mathrm{M} \mathrm{HF}$ at $293 \mathrm{~K}$ [7]. Prompted by these differing values, we 
calculated uranyl speciation for the solution composition of Fig. 1 of Moriyasu and coworkers' paper[5] using the more recent stability constants of Ahrland and Kullberg[10]. Our values, shown in Fig. 4a, differ little from Fig. 1 of Moriyasu and coworkers. However, given the technical difficulties of $\mathrm{pH}$ measurement and ionic strength adjustment in solutions containing significant amounts of $\mathrm{HF}$, Moriyasu and coworkers may have carried out serial addition of $\mathrm{NaF}$ to an $0.01 \mathrm{M}$ uranyl solution that initially was $\mathrm{pH}=1$ and ionic strength $=1$. In such a case, solution $\mathrm{pH}$ would have varied from acidic to near neutral. Our calculations for this case are shown in Fig. 4b (we did not correct for increased ionic strength due to addition of fluoride as $\mathrm{NaF}$ ). In Fig. $4 \mathrm{~b}, \mathrm{UO}_{2} \mathrm{~F}_{2}$ is the dominant uranyl fluoride species over a smaller fluoride concentration range and most uranyl at $1 \mathrm{M}$ total fluoride is $\mathrm{UO}_{2} \mathrm{~F}_{4}{ }^{2-}$ rather than $\mathrm{UO}_{2} \mathrm{~F}_{2}$. The $6667 \mathrm{~s}^{-1}$ decay rate reported by Moriyasu and coworkers and the dominance of $\mathrm{UO}_{2} \mathrm{~F}_{4}{ }^{2-}$ at $1 \mathrm{M}$ fluoride (if Fig. $4 \mathrm{~b}$ represents their work) agree with the $6250 \mathrm{~s}^{-1}$ decay rate reported by Billing and coworkers[6] for uranyl in $0.5 \mathrm{M} \mathrm{NaF}$ at $\mathrm{pH}=7.4$ (attributed by them to $\mathrm{UO}_{2} \mathrm{~F}_{4}{ }^{2-}$ ).

The much longer luminescence lifetimes observed in the present work and also reported by Moulin and coworkers in $0.67 \mathrm{M} \mathrm{HF[7],} \mathrm{in} \mathrm{comparison} \mathrm{with} \mathrm{those} \mathrm{reported} \mathrm{by} \mathrm{Moriyasu} \mathrm{and}$ coworkers [5] and Billing and coworkers[6], can be understood in terms of uranyl fluoride equilibria that are influenced by whether or not such complexes are electronically excited. If we assume that equilibrium occurs, on the time scale of the observed luminescence, among $\mathrm{UO}_{2} \mathrm{~F}^{+}$, $\mathrm{UO}_{2} \mathrm{~F}_{2}, \mathrm{UO}_{2} \mathrm{~F}_{3}{ }^{-}$, and $\mathrm{UO}_{2} \mathrm{~F}_{4}{ }^{2-}$ and $\mathrm{F}^{-}$, for electronically excited uranyl species (denoted by an asterisk in equilibrium reactions), we can model the observed data shown in Fig. 3. From a recent NMR study [17], the fluoride ion exchange rate for ground state uranyl fluorides is slower their luminescence decay rates. However, several luminescence studies, including work on uranyl sulfate [18] and nitrate [19] complexes, have concluded that ligand exchange rates for 
complexes of electronically excited uranyl can be so rapid that equilibrium is achieved on the luminescence time scale. Fixing the luminescence decay rate of $\mathrm{UO}_{2} \mathrm{~F}^{+}$at $13333 \mathrm{~s}^{-1}$ [5] and that of $\mathrm{UO}_{2} \mathrm{~F}_{4}{ }^{2-}$ at $6250 \mathrm{~s}^{-1}[6]$ and carrying out nonlinear least squares adjustment, gives the solid line shown in Fig. 3 for fit values of $8044 \mathrm{M}^{-1}$ for the equilibrium constant for formation of $\mathrm{UO}_{2} \mathrm{~F}_{2}$ * via $\mathrm{UO}_{2} \mathrm{~F}^{+*}+\mathrm{F}^{-} \rightarrow \mathrm{UO}_{2} \mathrm{~F}_{2}{ }^{*}$, of $0.7868 \mathrm{M}^{-1}$ for formation of $\mathrm{UO}_{2} \mathrm{~F}_{3}{ }^{*}$ via $\mathrm{UO}_{2} \mathrm{~F}_{2}{ }^{*}+\mathrm{F}^{-} \rightarrow \mathrm{UO}_{2} \mathrm{~F}_{3}{ }^{-}$ *, of $1.053 \times 10^{-4} \mathrm{M}^{-1}$ for formation of $\mathrm{UO}_{2} \mathrm{~F}_{4}{ }^{2-*}$ via $\mathrm{UO}_{2} \mathrm{~F}_{3}{ }^{-*}+\mathrm{F}^{-} \rightarrow \mathrm{UO}_{2} \mathrm{~F}_{4}{ }^{2-*}$ and of $3799 \mathrm{~s}^{-1}$ and $11850 \mathrm{~s}^{-1}$ as the luminescence decay rates of $\mathrm{UO}_{2} \mathrm{~F}_{2}$ and $\mathrm{UO}_{2} \mathrm{~F}_{3}{ }^{-}$, respectively. Free fluoride ion concentration, $\left[\mathrm{F}^{-}\right]$(see Fig. 3), was calculated using the stability constants of Ahrland and Kullberg[10] without correction for changes in ionic strength. Due to low total uranyl concentration, there is negligible change in $\left[\mathrm{F}^{-}\right]$due to speciation changes resulting from electronic excitation of uranyl fluorides. For the stated model parameters, the calculated decay rate for trace level uranyl in $0.67 \mathrm{M} \mathrm{HF}$ at $299 \mathrm{~K}$ is $3972 \mathrm{~s}^{-1}$, which differs little from the $293 \mathrm{~K}$ value of $3333 \mathrm{~s}^{-1}$ that was reported by Moulin and coworkers with no error limit stated [7]. Similarly, the calculated decay rate of dilute uranyl in $0.5 \mathrm{M}$ added NaF and $299 \mathrm{~K}$ is $6041 \mathrm{~s}^{-1}$, which differs little from the $6250 \mathrm{~s}^{-1}$ value assumed for $\mathrm{UO}_{2} \mathrm{~F}_{4}{ }^{2-}$, based on the work of Billing and coworkers at "room temperature" [6]. The calculated decay rate in $1 \mathrm{M} \mathrm{HF}+1 \mathrm{M} \mathrm{HClO}_{4}$ at $299 \mathrm{~K}$ is $4774 \mathrm{~s}^{-1}$. As expected, the calculated decay rate for uranyl fluorides at very low [F] is $13333 \mathrm{~s}^{-1}$, i.e., the reported value for $\mathrm{UO}_{2} \mathrm{~F}^{+}$[5]. Our model also provides a rationale for the similarity, noted above, of the reported emission spectra of uranyl in weakly to strongly acid solutions that contain fluoride. Our model predicts that emission from $\mathrm{UO}_{2} \mathrm{~F}_{2}$ accounts for $71 \%$, $91 \%$, and $94 \%$ of the emitted photons from uranyl fluorides at $299 \mathrm{~K}$ in, respectively, $1 \mathrm{M} \mathrm{HF}+$ $1 \mathrm{M} \mathrm{HClO}_{4}, 0.5 \mathrm{M} \mathrm{NaF}$ at $\mathrm{pH} 2$, and $0.67 \mathrm{M} \mathrm{HF}$ following $337 \mathrm{~nm}$ excitation. 
What is not immediately evident is the reason why Moriyasu and coworkers found no decay rate slower than $6667 \mathrm{~s}^{-1}$. If we assume that Fig. $4 \mathrm{~b}$ represents their work, then only their reported lifetime data points from $0.03 \mathrm{M}$ to $0.011 \mathrm{M}$ fluoride are significantly different than those that we calculate using our fitted equilibrium constants and luminescence decay rates and $\left[\mathrm{F}^{-}\right]$as calculated for Fig. $4 \mathrm{~b}$. The calculated HF concentration for Fig. $4 \mathrm{~b}$ rises rapidly to its maximum value $(0.089 \mathrm{M})$ over the range of $0.03 \mathrm{M}$ to $0.15 \mathrm{M}$ added $\mathrm{NaF}$. Due to the presumably long (but unstated) time necessary for Moriyasu and coworkers[5] to acquire a luminescence decay curve using a pulsed discharge in $\mathrm{N}_{2}$ gas as the light source, it may be that HF attack on their sample cell was significant and altered solution $\mathrm{pH}$ sufficiently to suppress the otherwise expected dominance of $\mathrm{UO}_{2} \mathrm{~F}_{2}$ and $\mathrm{UO}_{2} \mathrm{~F}_{3}{ }^{-}$in the range of $0.03 \mathrm{M}$ to $0.11 \mathrm{M}$ added $\mathrm{NaF}$. In addition, the possibility of self-quenching of uranyl luminescence in the work of Moriyasu and coworkers can not be ruled out due to the relatively high uranyl concentration that they used. Finally, basic impurities in $\mathrm{NaF}$ (such as those reported by Ahrland and Kullberg in their work [10]), if present, would have converted uranyl to $\mathrm{UO}_{2} \mathrm{~F}_{4}{ }^{2-}$ more rapidly over the concentration range in question and so rendered observation of the slow luminescence decay of $\mathrm{UO}_{2} \mathrm{~F}_{2}$ more difficult in the work of Moriyasu and coworkers [5].

The relatively weak quenching of uranyl fluoride luminescence by nitrate and tungstate ions found in the present work suggests that high sensitivity determination of the $\mathrm{UF}_{6}$ content of $\mathrm{WF}_{6}$ gas should be feasible via luminescence determination of uranyl following hydrolysis of impure $\mathrm{WF}_{6}$ gas in dilute nitric acid solution. Even higher sensitivity would be expected if dilute perchloric acid is used for hydrolysis of $\mathrm{WF}_{6}$ gas. Determination of trace level uranium in $\mathrm{Zr}$ metal has been demonstrated using uranyl luminescence following dissolution of the metal in $0.67 \mathrm{M} \mathrm{HF}+0.11 \mathrm{M} \mathrm{HNO}_{3}[7]$. 


\section{Conclusions}

Long lived, temperature dependent, single exponential luminescence decay of uranyl in $1 \mathrm{M} \mathrm{HF}+1 \mathrm{M} \mathrm{HClO}_{4}$ has been observed and is attributed to emission predominantly from $\mathrm{UO}_{2} \mathrm{~F}_{2}$ based on uranyl speciation calculations and a luminescence dynamics model that assumes that electronically excited uranyl fluorides are in equilibrium with each other and free $\mathrm{F}^{-}$ion on the luminescence decay time scale. The model accounts for the observed luminescence dynamics and spectra of uranyl fluorides in aqueous solution following near ultraviolet excitation of acidic solutions containing significant amounts of fluoride. Relatively weak quenching of uranyl fluoride luminescence by tungstate and nitrate ions suggests that high sensitivity determination of the $\mathrm{UF}_{6}$ content of $\mathrm{WF}_{6}$ gas should be feasible via uranyl luminescence analysis of hydrolyzed gas samples of impure $\mathrm{WF}_{6}$.

\section{Acknowledgments}

This work was performed under the auspices of the Office of Basic Energy Sciences, Division of Chemical Sciences, U. S. Department of Energy under contract W-31-109-ENG-38.

\section{DISCLAIMER}

This report was prepared as an account of work sponsored by an agency of the United States Government. Neither the United States Government nor any agency thereof, nor any of their employees, makes any warranty, express or implied, or assumes any legal liability or responsibility for the accuracy, completeness, or usefulness of any information, apparatus, product, or process disclosed, or represents that its use would not infringe privately owned rights. Reference herein to any specific commercial product, process, or service by trade name, trademark, manufacturer, or otherwise does not necessarily constitute or imply its endorsement, recommendation, or favoring by the United States Government or any agency thereof. The views and opinions of authors expressed herein do not necessarily state or reflect those of the United States Government or any agency thereof. 


\section{References}

1. A. A. Zinn, in T. T. Kodas and M. J. Hampden-Smith (eds.), The Chemistry of Metal CVD, VCH, Weinheim, 1994, pp.107-171.

2. M. Fukuma, H. Furuta, and M. Takada, Proc. IEEE, 81 (1993) 768.

3. M. Moriyasu, Y. Yokoyama, and S. Ikeda, J. Inorg. Nucl. Chem., 39 (1977) 2205.

4. R. Kaminski, F. J. Purcell, and E. Russavage, Anal. Chem., 53 (1981) 1093.

5. M. Moriyasu, Y. Yokoyama, and S. Ikeda, J. Inorg. Nucl. Chem., 39 (1977) 2199.

6. R. Billing, G. V. Zakharova, L. S. Atabekyan, and H. Henning, J. Photochem. Photobiol. A: Chem., 59 (1991) 163.

7. C. Moulin, P. Decambox, and L. Trecani, Anal. Chim. Acta, 321 (1996) 121.

8. M. E. D. G. Azenha, H. D. Burrows, S. J. Formosinho, M. G. M. Miguel, A. P. Daramanyan, and I. V. Khudyakov, J. Lumin., 48 \& 49 (1991) 522.

9. J. C. Sprott, Numerical Recipes: Routines and Examples in Basic, Cambridge University Press, Cambridge, 1991. 
10. S. Ahrland and L Kullberg, Acta Chem. Scand., 25 (1971) 3457.

11. M. Arvis, N. Keller, G. Folcher and B. Hickel, J. Photochem., 21 (1983) 313.

12. H. Deniau, P. Decambox, P. Mauchien, and C. Moulin, Radiochim. Acta, 61 (1993) 23

13. Kh. B. Kushkov, V. I. Shapoval, S. G. Gasviani, and A. A. Tischenko, Sov. Electrochem., 28 (1992) 117.

14. D. D. Afonichev, L. A. Khamidullina, A. V. Mamykin, and V. P. Kazakov, Sov. Radiochem., $28(1986) 644$.

15. I. Grenthe, J. Fuger, R. J. M. Konings, R. J. Lemire, A. B. Muller, C. Nguyen-Trung, and H. Wanner, Chemical Thermodynamics of Uranium, North-Holland, Amsterdam, 1992, pp. 159-160.

16. R. M. Smith and A. E. Martell, Critical Stability Constants, vol. 6, Plenum, New York, 1986, p. 453.

17. Z. Szabo and J. Glaser, Mag. Reson. Chem., 33 (1995) 20. 
18. S. S. Ostakhov, V. P. Kazakov, D. D. Afonichev, and V. V. Rykova, Radiochem., 37 (1995) 503.

19. M. D. Marcantonatos, M. Deschaux, and F. Celardin, Chem. Phys. Let., 69 (1980) 144. 


\section{Figure Captions}

Fig. 1. Emission spectra of $1.3 \times 10^{-5} \mathrm{M}$ uranyl in $1 \mathrm{M} \mathrm{HF}+1 \mathrm{M} \mathrm{HClO}_{4}$ at $301 \mathrm{~K}(320 \mu$ s wide analyzer gate, opened $2.6 \mu$ s before each $337 \mathrm{~nm}$ excitation pulse). Curve a, shown with linear and logarithmic axes, was recorded prior to addition of any $\mathrm{LiNO}_{3}$. Curve $\mathbf{b}$, scaled in intensity so that its most prominent peak has the same peak-to-valley ratio as the corresponding peak of curve $\mathbf{a}$, was recorded after addition of $0.98 \mathrm{M} \mathrm{LiNO}_{3}$. Curve $\mathbf{c}$ is the result of subtracting curve a from curve $b$.

Fig. 2. The observed luminescence decay of $1.3 \times 10^{-5} \mathrm{M}$ uranyl ion in $1 \mathrm{M} \mathrm{HF}+1 \mathrm{M} \mathrm{HClO}_{4}$ at $296 \mathrm{~K}$, following $337 \mathrm{~nm}$ excitation, is shown as symbols (every 20th datum shown) along with the best fit single exponential decay curve (solid line, $\mathrm{k}_{1}=3718 \mathrm{~s}^{-1}$ ).

Fig. 3. Observed luminescence decay rate versus concentration of added $\mathrm{NaF}$ for a solution at $299 \mathrm{~K}$ that initially contained $3 \times 10^{-6} \mathrm{M}$ uranyl in $0.1 \mathrm{M} \mathrm{HClO}_{4}$ (symbols) and the best fit curve (solid line) for a model, described in the text, that assumes equilibrium among electronically excited uranyl fluorides and free fluoride ion. Also shown is the free fluoride ion concentration resulting from addition of $\mathrm{NaF}$ that was calculated using the stability constants of Ahrland and Kullberg [10].

Fig. 4. Calculated concentration of uranyl species ( $0.01 \mathrm{M}$ total uranyl) as a function of total fluoride ion concentration in $\mathrm{pH}=1$, ionic strength $=1$ solutions at $298 \mathrm{~K}$. (panel a). Calculated concentration of uranyl species as a function of added $\mathrm{NaF}$ for a solution initially $0.01 \mathrm{M}$ in uranyl, $\mathrm{pH}=1$, and ionic strength $=1$ at $298 \mathrm{~K}$ (panel b). 


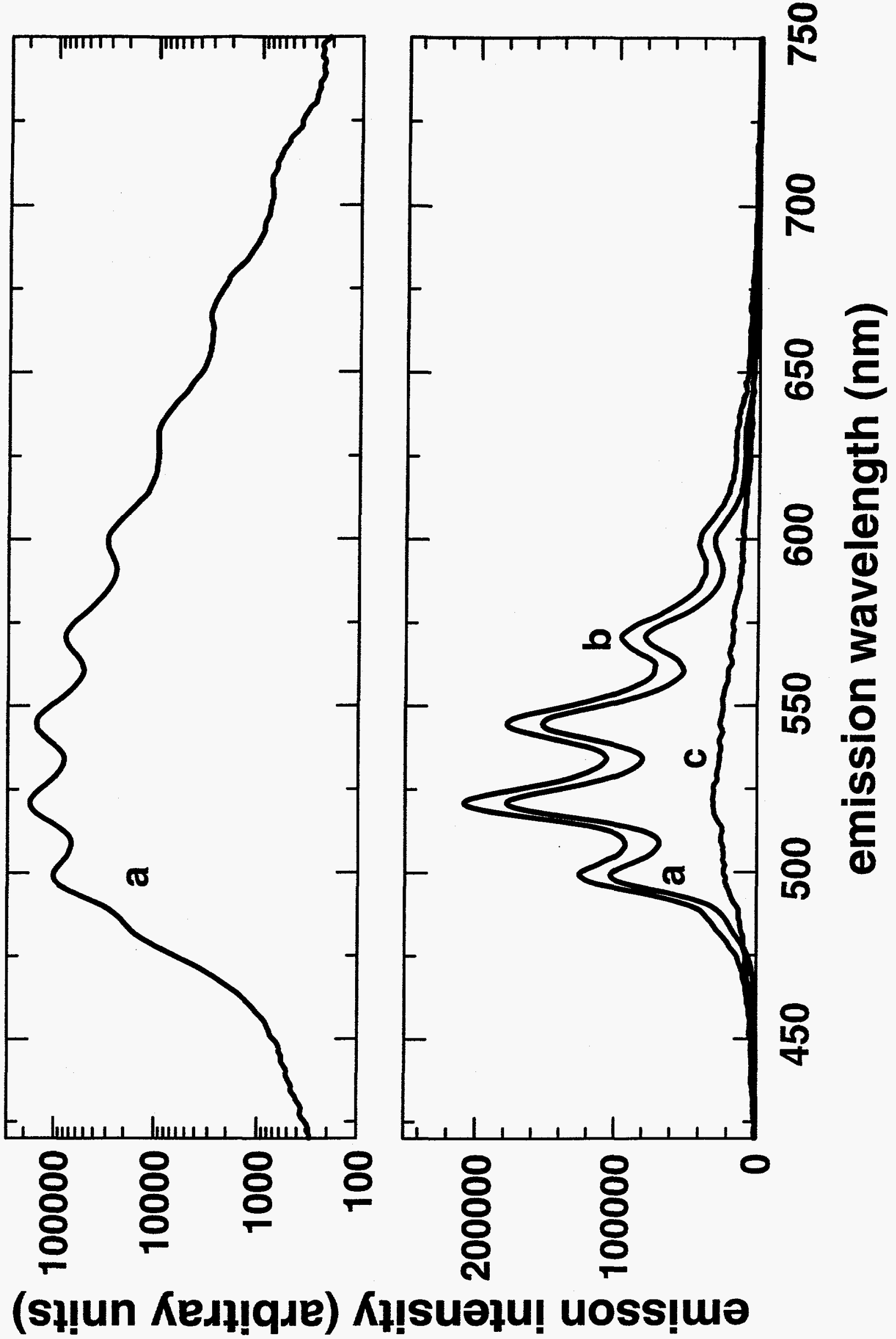




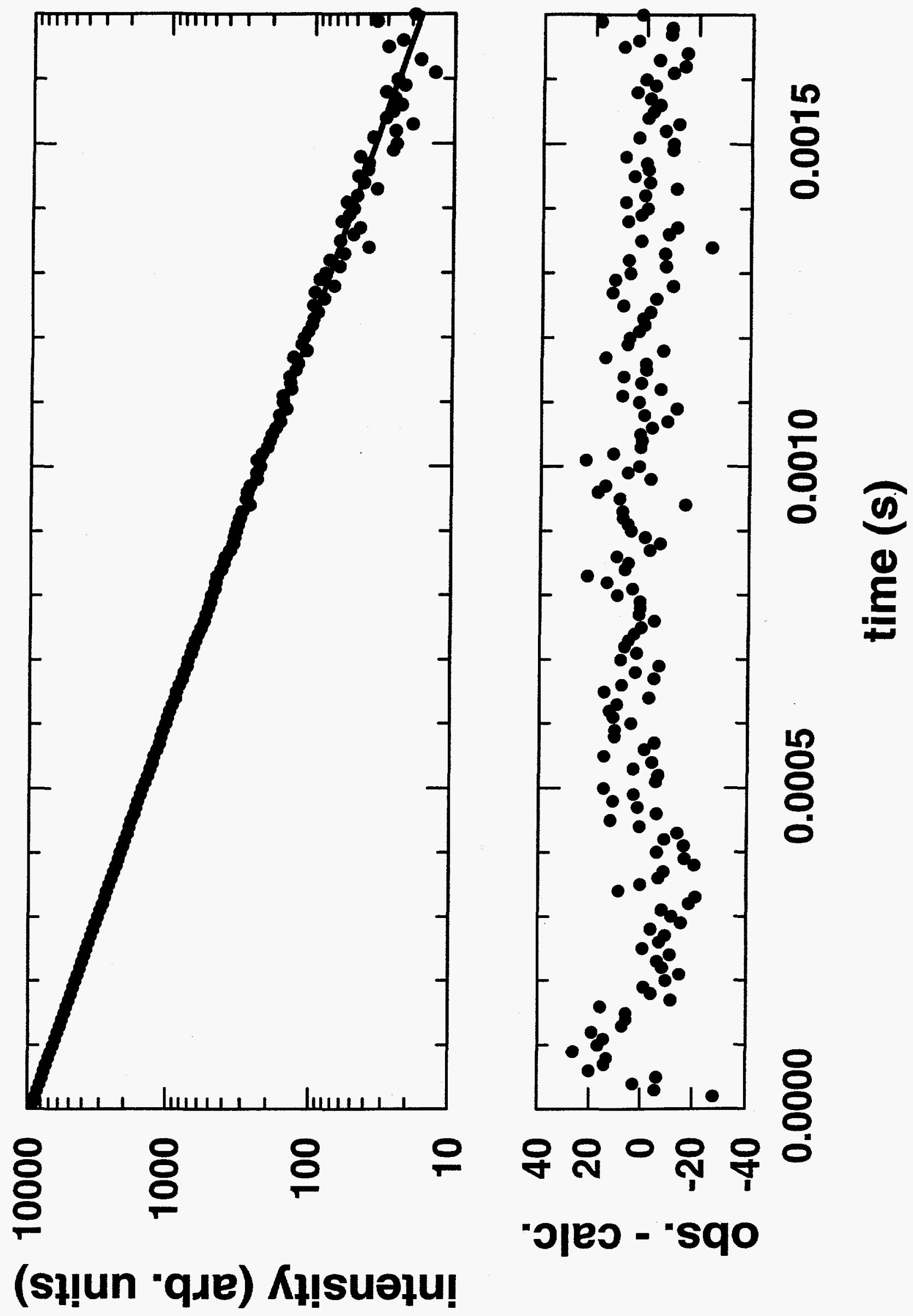


$\frac{T}{\omega}$
$\omega$

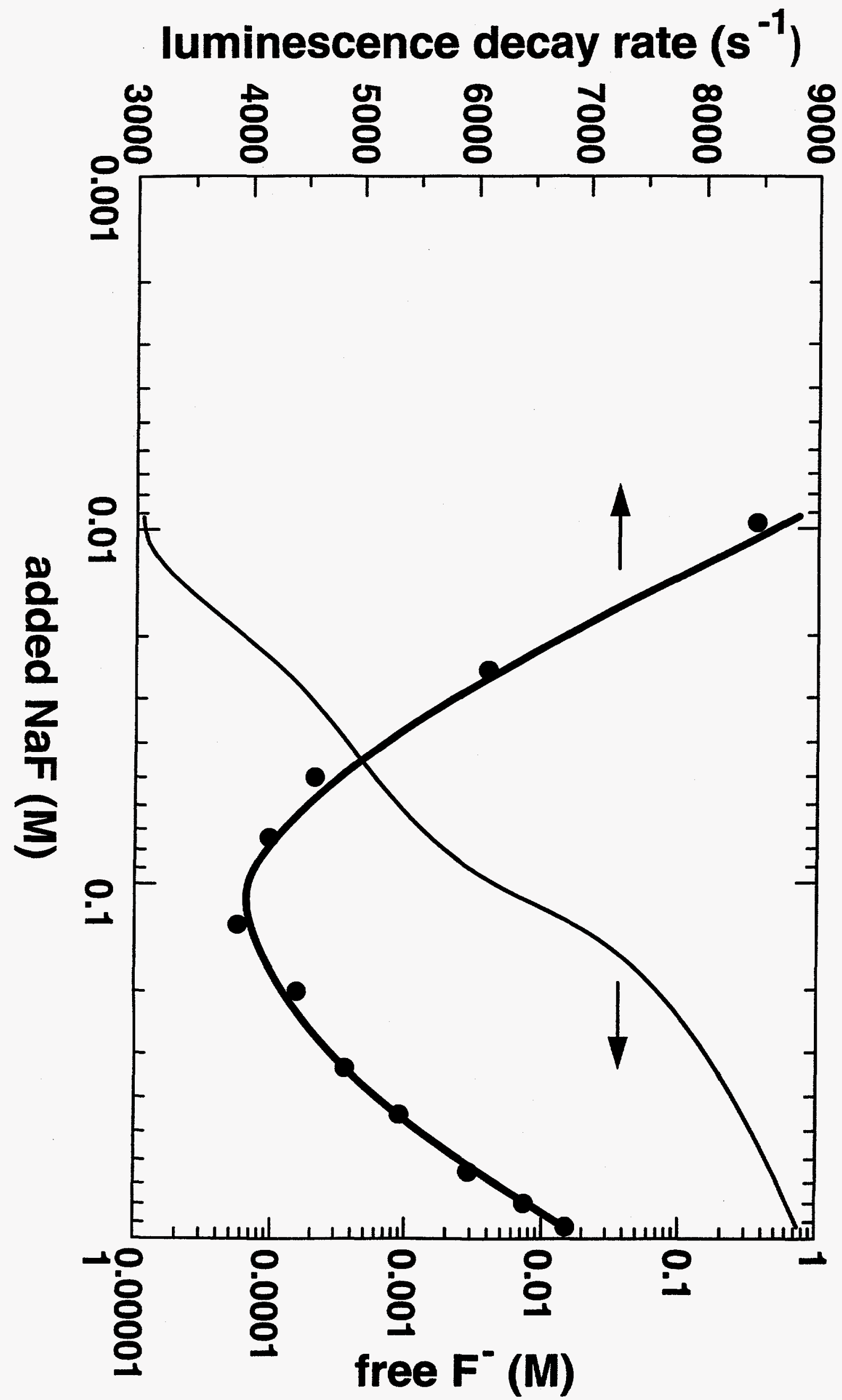




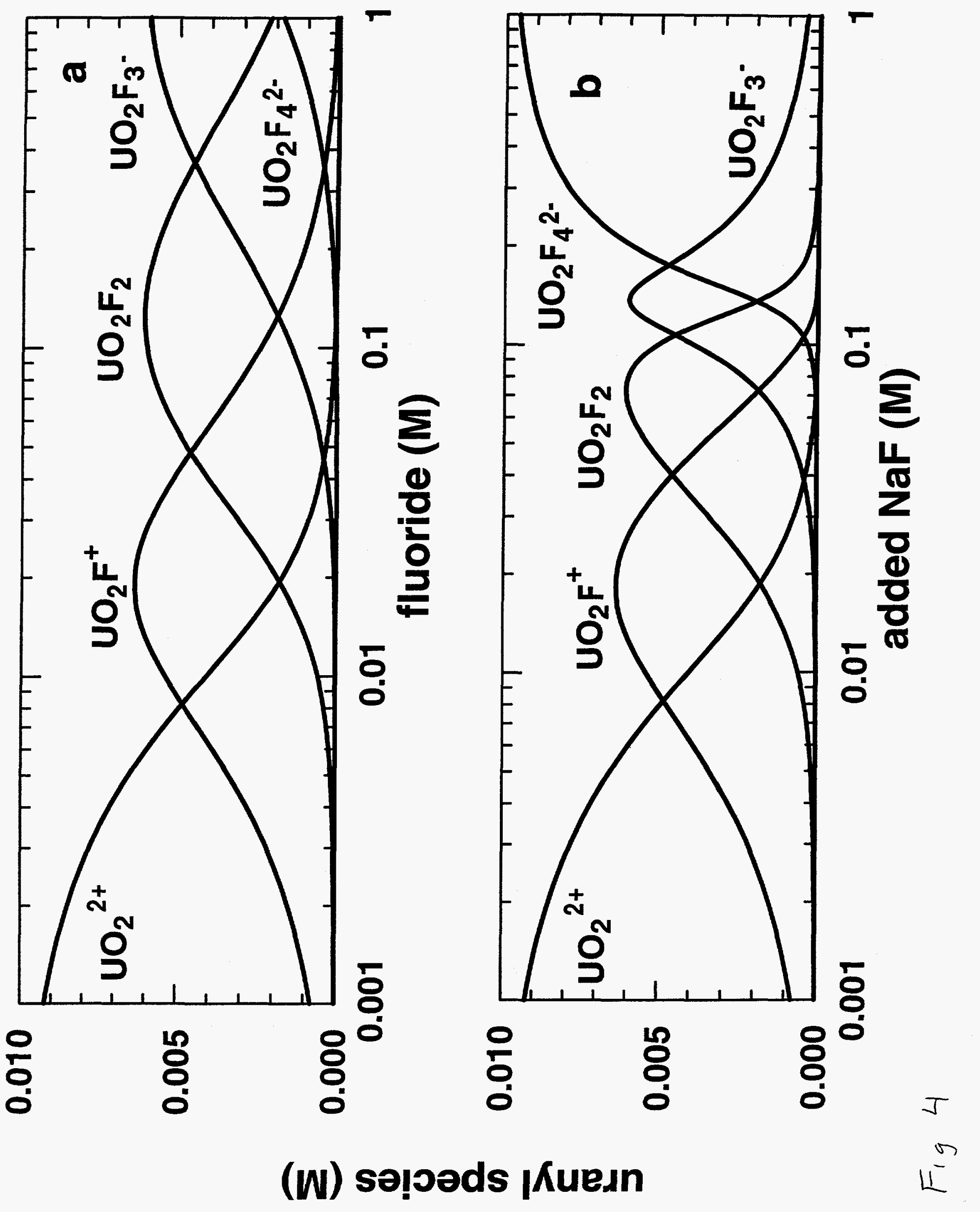

